\title{
Postsocialism, borders, security and race after Yugoslavia
}

The historical legacies shown in the last chapter do much to explain the contradictory racialised imaginaries of the Yugoslav region's 'cultural archive' (Chapter 1) and the shifting nature of translations of race into discourses of ethnic and national belonging (Chapter 2). Though many past applications of postcolonial thought to south-east Europe have bracketed race away, identifications with racialised narratives of Europeanness predated state socialism, yet alone the collapse of Yugoslavia which, it is sometimes thought, opened space for new postsocialist racisms. Translations of broader racialised discourses in the 1990s indeed took distinctive forms, embedded in a transnational European 'cultural racism' (Balibar and Wallerstein 1991: 26) consolidating nationalisms around a common defensive project of securing Europe against supposedly culturally alien, unassimilable migrant Others from Africa and Asia (Lentin 2004; Fekete 2009). Culturalist narratives of Europeannessas-modernity and Europeanness-at-risk entered traditionalistconservative and liberal national identity discourses most evidently in Slovenia (Mihelj 2005; Petrović 2009; Longinović 2011), but also elsewhere. Identity narratives at the north-west end of 'nesting orientalisms' (Bakić-Hayden 1995) trained racialising lenses south-east across the Balkans towards Muslim and dark-skinned refugees and migrants entering Europe. Slovenian and Croatian nationalism's performative rejection of Yugoslav state socialism and Yugoslav multi-ethnicity appeared to have also swept Yugoslav anti-colonial solidarities away.

While post-Yugoslav identifications with cultural racism went back too far simply to be 'consequences' of postsocialism, the region's violently 
inverted geopolitical position after 1990 still shaped what form they took. The ethnopolitical violence that political entrepreneurs, paramilitaries and organised criminals stimulated as the Yugoslav regime collapsed left a country that had imagined itself a hub of East-West-South cooperation, and a society that had believed Yugoslavs enjoyed greater global mobility than citizens of either East or West (Jansen 2009), subject to peacekeeping and humanitarian intervention by the very global institutions Tito's Yugoslavia had hoped to lead. Other European governments no longer saw the region as exporting skilled professionals and managed numbers of guest-workers but as a source of international instability (Hansen 2006) and disordered refugee flows, as millions escaped violent ethnicised displacement from Croatia, BosniaHerzegovina and later Kosovo or systemic structural inequality (exacerbated in Serbia by economic sanctions against Milošević) elsewhere. Security-minded gazes from northern and western Europe categorised Bosnia alongside Rwanda and Somalia, imagining all three complex conflicts as primarily driven by ethnic hatred (Pieterse 1997) - though conditionally white, conditionally European Bosnian refugees could still come closer to western European collective selves than black African refugees in hierarchies of foreignness based on 'cultural distance' (Eastmond 1998: 176). ${ }^{1}$ This heavily racialised identification of the Yugoslav region and Africa from outside inverted the discourses of modernisation, anti-colonialism and solidarity through which Tito and some Non-Aligned travellers had imagined Yugoslav-African brotherhood - while participation in European/transatlantic security and border projects would create new opportunities for identification with whiteness and the West. Perceiving the postcoloniality of postsocialism requires appreciating this contradiction.

\section{'New' postsocialist racisms and the Yugoslav wars}

Societies across central and eastern Europe, not just the Yugoslav region, witnessed an 'increasingly visible ethno-nationalism' - in revivals of 
narratives of national victimhood, prominent public roles for religious organisations, constriction of women's public participation, demographic panics about ethnic majorities, and weakened reproductive rights - after state socialism collapsed (Verdery 1994: 250). Racism and xenophobia against Roma, Jews, other minorities and historic ethnic Others, plus undocumented migrants crossing into the EU, were another dimension of postsocialist 'nation-building' (Bošković 2006: 560), creating what the Slovenian sociologist Tonči Kuzmanić (2002: 21) termed a 'new ... post-socialist race matrix' at an international workshop on xenophobia and postsocialism that he and colleagues at the Peace Institute, Ljubljana, convened in 2001. Even in comparative context, post-Yugoslav cases stood out: partly because of the distinct role that anti-colonial friendship had had in Titoist identity, and, most visibly, because postsocialism in this region entailed not just economic and political shock but war itself.

The 'newness' of post-Yugoslav racisms, Kuzmanić (2002: 22) thought, was that they targeted the 'free floating signifiers' of cultural racism rather than following older European and US racisms' biological essentialism. 'Cultural racism' also helps Julija Sardelić explain rising post-Yugoslav antiziganism, which regarded Roma as not even capable of forming their own territorial nation. Sardelić (2014: 208-9) links this form of racism into wider contexts of 1990s European racisms via perspectives from Britain (Gilroy), France (Pierre-André Taguieff) and Italy (Michael Hardt and Antonio Negri) which argue there are multiple racisms that mobilise 'constructed cultural difference' to legitimise majorities' hierarchical advantage. Gilroy's argument that ' $r$ r]acism ... assumes new forms and articulates new antagonisms through time and history' (Gilroy 1987: 11), which Sardelić (2014: 208) quotes, enables him to read attacks on multi-ethnic cultural heritage in Sarajevo ordered by Republika Srpska (RS) authorities as part of the same conflict between 'neo-fascism' and pluralist democracy that motivated Front Nationalecontrolled municipalities in 1990s France to seek to ban films with queer content or rap music resisting police (Gilroy 2000: 280). Still, biological racism had not disappeared: the RS leadership grounded its belief in the Otherness and inhumanity of Bosniaks not just on culture 
but also on vehement biological racism based on psychiatry and genetics. Radovan Karadžić's pre-war career as a psychiatrist and Biljana Plavšić's as a biologist were not surreal wartime curiosities; ${ }^{2}$ they were articulations of science and racism that became tools for the RS leadership to graft scientific authority on to a campaign for ethnically pure territory, with Plavšić in 1993 calling Bosniaks 'genetically deformed material [South Slav stock] that embraced Islam' (Sells 1996: xiv-Xv). Their pseudoscience connected the genocidal project with European rationality and modernity. ${ }^{3}$

More 'new antagonisms' in post-Yugoslav racisms evolved away from the frontlines and after wars' end. The most linkages between xenophobia based on post-Yugoslav ethnicised identity boundaries and xenophobia against racialised immigrants from outside the region have been found for Slovenia. Slovenian campaigners for multi-party democracy in late state socialism had framed their programme as demanding 'Europe', and Slovenia's pathway towards EU accession was indeed the Yugoslav region's quickest. ${ }^{4}$ Amid a widening wealth gap between Slovenia and the south-eastern republics in the 1980s, Slovenian resentment towards economic migrants from these areas (especially Albanians and Roma, but also Macedonians and Serbs) - which Longinović (2011: 98) called a 'soft version of cultural racism' itself - was already perceptible. Slovenia's citizenship law passed after independence in June 1991 wrote this hierarchy into legislation by requiring non-Slovene permanent residents to apply for naturalisation, rather than granting them citizenship as it did ethnically Slovene residents; 18,000, the so-called 'erased', were left without legal status after removal from the residency register in 1992 (Zorn 2009: 289-92; Kogovšek Šalamon 2016).

Slovenian responses to the 1992-5 Bosnian refugee crisis and 2000-1's sharp increase in undocumented migrants have been seen as strikingly similar, both mobilising myths of the Slovenian border as the symbolic boundary between, first, Europe and the Balkans, and, secondly, Europe and an even less well-defined space of racialised Otherness (Žagar 2002). This was despite the same supranational Yugoslav identity having addressed Slovenes and Bosnians for decades, and indeed the 
solidarities with the Third World that Non-Aligned internationalism aimed to develop among Yugoslavs. Slovenian authorities gave Bosnians 'temporary protection' (not refugee) status, restricted them to refugee centres, excluded them from paid employment and educated refugee children separately, rather than foreseeing their integration into Slovenian society (Vrecer 2010). In 2000, a year when 13,000 rather than the past year's 776 people (mostly from the Middle East and south-east Asia) claimed asylum, Slovenian media revived the frame of migrants and refugees as likely criminals and public-health risks such that Slovenes might reasonably object to having refugee centres near their homes (Mihelj 2005: 120). ${ }^{5}$ Articulations of Slovenian nationalism in both crises involved notions of autochthony linking Slovenian ethnicity to homeland, defining the nation against immediate regional Others and newer external Others at once (Mihelj 2004: 12) - to the extent that remaining Bosnian refugees in 2000-1 started being viewed as less threatening, and in this shifting racial order 'refugee' started signifying migrants with more rights than the less-deserving new 'asylum-seekers' or 'illegals' (Žagar 2002: 38). The 'xeno-racism' (Fekete 2009: 19) characterising the politics of asylum in turn-of-the-millennium Europe certainly extended into Slovenia.

Among all post-Yugoslav national identities, Slovenia’s had the most resources for performing membership of a culturalist 'European' space, able to tolerate refugees in well-regulated amounts but not so much as to threaten the national socio-cultural fabric. Even other post-Yugoslav nationalisms, however, contained racialised exclusions. Croat and Serb nationalists both racialised Bosnian Muslims as Turks during the Bosnian conflict, though Croat nationalism gave them a much more ambiguous role: though Croats' identification with Catholic and Christian Europe placed Bosniaks across a major symbolic boundary, narratives of Croats and Bosniaks as joint victims of Serbian aggression, and even the NDH myth of Bosniaks as 'Islamicised Croats', could bring Bosniaks potentially closer in the eyes of Croats than in the eyes of Serbs. In practice, dominant Croatian discourses about Bosniaks followed Bosniak-Croat political/ military relations in Bosnia-Herzegovina itself. When the Bosnian branch 
of Croatia's ruling party $\left(\mathrm{HDZ} \mathrm{BiH}^{6}\right)$ and the Croat Defence Council (HVO, the Bosnian Croat armed forces) were allied with the Sarajevo government and the Bosniak-nationalist Party of Democratic Action (SDA), Croatian state media depicted Bosniak refugees more sympathetically, as common victims of Serb aggression; while during the 1993-4 Bosniak-Croat conflict and after the Dayton Peace Agreement (when $\mathrm{HDZ} \mathrm{BiH}$, still antagonistic towards the settlement, looked towards future union with Croatia and demanded a 'third entity'), they highlighted Bosniaks' Islamic characteristics, plus Croat accounts of victimisation by Muslims. Yet, beyond the hardening of ethnicised boundaries into racialised categories in wartime nationalisms, post-Yugoslav racisms also surpassed the intra-regional and construct civilisational hierarchies between their white, European nation and stereotypes of black, brown and Asian (or 'Chinese') peoples, supposedly unprepared for modernity. The politics of racism and peacekeeping in the Yugoslav wars exemplified how post-Yugoslav racisms mediated the geopolitical reversal that many ex-Yugoslavs felt they had undergone.

\section{Racism, peacekeeping and international intervention}

One 'global' racism in 1990s Croatia and Bosnia-Herzegovina channelled resentment that the humanitarian and securitising Western gaze had suddenly ascribed ex-Yugoslavs the same status as Africans (i.e. objects of pity and mistrusted visa nationals) on to the figure of the African peacekeeper. In April 1995, negotiating a post-war UN peacekeeping mandate, the Croatian government was forced to deny reports it had insisted on no African or Asian states participating (O'Shea 2005: 145). Bangladesh, Pakistan, India and Malaysia had been among the larger United Nations Protection Force (UNPROFOR) contributors in Croatia and Bosnia-Herzegovina, and UNPROFOR's first commander (a public figure) was an Indian general, Satish Nambiar. Kenya and Nigeria both contributed UNPROFOR infantry battalions in 1992 and other African countries sent smaller numbers of peacekeepers or 
military observers (Tatalović 1993: 58). ${ }^{7}$ Racialising UNPROFOR let harder-line Croatian nationalists express how unwanted they considered the UN presence.

The semi-anonymous, satirically named 'UNPROFOR Big Band', one of many fringe acts expressing vituperative patriotism in wartime Croatian music (Pettan 1998a), illustrated their 1993 cassette with a cartoon monkey in a blue UN helmet, 'an obvious commentary on the number of black soldiers' (Longinović 2000: 638) in UNPROFOR. Their abusive lyrics, set to Slavonian tamburica music and subjecting male and female Serb nationalist leaders to imagined sexual and scatological assault, treated UNPROFOR and Nambiar as the same kind of racialised invader $^{8}$ - conflating an occupying military/paramilitary force with a UN peacekeeping force deployed with Croatian governmental consent. Distance from internal ethnic Others (Serbs) and external racial Others (Africans, Indians, the UN) here ran together.

The internationalisation of the Bosnian conflict as humanitarian crisis and media spectacle, coinciding with failed UN interventions in Somalia (where the Somali National Alliance attacked the US-led peacekeeping force in 1993) and Rwanda (where post-civil-war peacekeepers failed to prevent the 1994 genocide), gave Western media ambiguous frames of reference for situating Bosnians and the Yugoslav region within a global geography of conflict. Western journalists' and travellers' representations of Bosnia, extending into other cultural forms, typically fell into two types, each implying a certain stance towards intervention. The 'Balkan discourse' attributed the violence to insoluble ancient 'ethnic' or even (with direct colonial overtones) 'tribal' hatreds, blamed all sides equally, and implied Western intervention would be futile. The 'genocide discourse' recognised Bosniaks (and sometimes Croats) as victims of Serb genocide and, implicitly or explicitly evoking the Holocaust, counselled military intervention to prevent another such extermination in Europe (Hansen 2006: 96). While the 'Balkan discourse' applied an orientalising lens of endemic, unknowable disorder, 'genocide discourse' brought the Balkans closer to 'Europe'. Yet both discourses - the extensive critical commentary on Western media and Bosnia 
notes this much more rarely - also racialised Bosnians differently: as somehow-Other (just as Europeanness and whiteness had long been constructed against African and Indigenous 'tribal' savagery) or as fellow whites.

Making 'the Balkans' a symbolic boundary-marker of distance from 'Europeanness' and modernity is, ultimately, a racialising move - dependent on imagining certain places as inherently incapable of rationality and development without the North's/West's civilising mission. This is, in critical race theory and especially for Charles Mills (1997), the underlying racialised principle behind every spatialised hierarchy of savagery versus modernity. Moreover, the rhetorical device of provoking Western audiences' shock at concentration camps being reintroduced in Europe (see Campbell 2002) arguably obscured genocides outside Europe and disavowed exterminations perpetrated by 'Europeans' against colonised peoples (Dauphinée 2013: 352). The implication that the unconscious biases of whiteness might have made images of suffering Bosnians easier for white Europeans and global Northerners to identify with, relative to images of black Africans experiencing conflict, hunger and genocide at the same moment, is both unsettling and necessary to confront.

Bosnia's comparability with Rwanda and Somalia had racialised undertones even in Bosnia. When the British photojournalist Paul Lowe exhibited photographs from Sarajevo side by side with others from Somalia, Susan Sontag observed objections among Sarajevans which for Himadeep Muppidi (2013: 304) could reflect a deep 'European exceptionalism':

Undoubtedly there was a racist tinge to their indignation - Bosnians are Europeans, people in Sarajevo never tired of pointing out to their foreign friends - but they would have objected too if, instead, pictures of atrocities committed against civilians in Chechnya or in Kosovo, indeed in any other country, had been included[.] (Sontag 2003: 112-13)

Muppidi argues, against Sontag, that comparing Bosnia with other intra-European genocides (from which late-twentieth-century European 
understandings of genocide came) would have been different. Indeed, comparisons with Jewish suffering were an important moral instrument throughout the Yugoslav wars - even, in constructing narratives of national victimhood, among speakers implicated in ethnopolitical violence themselves (Macdonald 2003). If the attachment to urban identity that sustained besieged Sarajevans' morale and gave other cities' anti-nationalists moral faith helped 'relate one's personal narrative to the larger story of European modernity' (Jansen 2005: 162), it still contained an - almost certainly subconscious - whiteness within the racialised history of imagining 'Europe, writing Sarajevo and Somalia - however diffusely - into different parts of history.

These are sensitive, but important, identifications to contextualise when many people in the region, and those forced to emigrate by ethnopolitical violence and economic depredation, have expressed resentment at being treated like 'a third world country' (Jansen 2005: 160) or 'like Africans'. Whether to Bosnians fleeing besieged towns in the early 1990s or Serbians queuing for visas outside Western embassies in the late 2000s, this might have felt even more like a 'fall from grace' (Jansen 2009: 826) because of the state socialist myth that Non-Aligned Yugoslavia made its citizens more mobile than the superpower blocs'. Tanja Petrović (2009: 55) calls these discourses 'nesting colonialisms': post-Yugoslavs distancing themselves from the 'Third World' just as the EU and other Western institutions seemed to be pushing the region into it. The separation of Yugoslavs and the Third World into different geopolitical categories undid the international solidarities of NonAlignment - though might connote either that the Yugoslav region did belong on a higher rung of the global ladder, or that the 'Third World' did not deserve such treatment either.

Race and whiteness remained perceptible in post-war Bosnian identity discourses as new, open-ended forms of post-conflict international intervention developed - yet ethnographies of post-conflict-postsocialist Bosnia rarely discuss them. NATO's multinational military force (Implementation Force (IFOR) and Stabilization Force (SFOR)), which replaced UNPROFOR after Dayton, and the UN's International Police 
Task Force (IPTF) that monitored and assisted local police, occasioned numerous encounters between Bosnians and people of colour within an intervention that many Bosnians experienced as disempowering, unaccountable and indeed neo-colonial. ${ }^{9}$ If these were neo-colonial authorities, their embodiment was visibly multiracial - the IPTF's top contributors by July 1997 were the USA, Germany, India, Jordan, France, Pakistan and Ghana ${ }^{10}$ - and some Bosnians resented taking instructions from officers from countries they perceived were less well administered than Bosnia should have been. IFOR/SFOR involved notably fewer African forces than UNPROFOR, and none from sub-Saharan Africa. Even then, however, the colonial histories of forces from the Global North still brought a multiracial presence to Bosnia.

British forces' recruitment of Commonwealth soldiers and Gurkha regiments, a practice with colonial roots (Ware 2012), often for instance meant Bosnians encountering Nepalese and Pacific Islanders having expected predominantly white Britons, with formed Gurkha units causing most surprise. British forces leading IFOR/SFOR's Multi-National Division (North-West) stationed several Gurkha companies on bases around northern Republika Srpska in the late 1990s, and after 2003, with Britain fighting in Iraq as well as Afghanistan, depended heavily on Gurkha battalions to fulfil commitments to Bosnia-Herzegovina and Kosovo; local residents often racialised Gurkhas, at least initially, as 'Chinese'. Tuzla, meanwhile, was the centre of US military presence, which peaked at 20,000 in 1996 before scaling down to 5,000 then 1,000 in 1998-2004 (Phillips 2004). US force-protection policies, after the humiliation of Somalia, made social encounters between local residents and US personnel much more transitory in late-1990s Bosnia than during the post-Second World War Allied occupation of Germany, and African-American troops did not have similar cultural impact $^{11}$ - though Bosnians recruited through US military contractors for service occupations or translation/interpreting had more sustained contact with US troops.

One ex-interpreter, 'Tarik', whom I interviewed for a project on translation/interpreting and peacekeeping, remembered that among 
the US Army units posted to his Tuzla base had been an 'all-black' unit from Arkansas. He adapted to their African-American Vernacular English while building what he recalled as his best working relationship, where after a few months he already felt 'not [like] a Bosnian guy who's here to help them, but one of the team'. Their replacements, a New York unit, were not racialised the same way (speaking 'different English, without so much slang') and 'look[ed] at me like I'm from a different planet [...] if you see a Bosnian white person who speaks Ebonics, then it feels like something's wrong with this guy. But it just happened' (Kelly and Baker 2013: 183).

The co-author of our project's joint monograph read this encounter across racialised boundaries as having produced 'an identity which is not sustainable', leaving 'the cultural identity he has assumed ... in conflict with his social identity as a white Bosnian' (Kelly and Baker 2013: 184). Lenses of global raciality that I did not apply when editing our manuscript in 2012 would locate Tarik's discomfort, and perhaps even his racialisation as white, in the New Yorkers' remembered reactions to the disjuncture they perceived between appearance, ethnicity/ nationality and accent/dialect, more than stemming straight from his identity as Bosnian. The resultant social identity in the new interpersonal environment might well have been unsustainable. On one level, the account (narrated at least six to seven years later) revealed a disconnect between symbolic linguistic and embodied markers of race. In a broader view, however, it reiterates many other shifting identity-performances by Yugoslavs from various social and ethnicised subject positions, and perhaps even shows obliquely how US soldiers interacted with Bosnia and Bosnians through lenses inflected by their own racialised experiences at home. How might African-American soldiers from Arkansas, compared with white soldiers from either Arkansas or New York, have interpreted postsocialist Tuzla's war-damaged, privatised landscape, Tuzla's distinctive wartime history of resisting ethnonationalism in local government or enduring a targeted VRS mortar massacre of civilian teenagers, or indeed the stakes of the wider Bosnian war? Race, as well as ethnicity, is an essential category for understanding the micropolitics of postsocialism, 
and for situating the Yugoslav wars more widely in late-twentieth-century European history.

\section{The Yugoslav wars, European racisms and the 'migration-security nexus'}

Popular Western reductions of the Yugoslav wars to a decontextualised 'ethnic conflict' (Banks and Wolfe Murray 1999) contributed to scholarship itself focusing predominantly on ethnicity at the expense of economic dislocations when explaining the post-Yugoslav region. While sociologists and anthropologists were extensively researching the inequalities of postsocialist 'transition' in central Europe and the eastern Balkans, the Yugoslav region stood predominantly as a 'post-conflict' area, even though the socio-economic impacts of the collapse of socialism wove through the wars' origins and course (see Woodward 1995; Bougarel, Helms and Duijzings (eds) 2007; Archer, Duda and Stubbs (eds) 2016). Although the wars and their aftermath required a 'double lens' seeing the region as postsocialist and post-conflict, to most Western nonspecialists they were plain and simply an example of violent ethnic conflict. In this capacity, they informed post-Cold-War Western dynamics of race and an emerging 'migration-security nexus' (Faist 2006) where policymakers evaluated migrations as security threats.

To writers like Daniel Patrick Moynihan (1993), whose 'Moynihan Report' three decades earlier had stigmatised African-American family structures as the underlying cause of African-American poverty (Crenshaw 1991: 1254), or Samuel Huntington (1996), ethnic disorder characterised post-Cold-War international security. Some readings made it endemic to certain zones of the world that would threaten Western peace and prosperity unless strong borders sealed them off (Kaplan 1993); ${ }^{12}$ others made it the inevitable result of historically and geographically defined civilisational faultlines (Huntington 1996), or a phenomenon that alongside neo-Nazi attacks on refugees in Germany and sectarian violence in Northern Ireland revealed a resurgent, ethnic 'new nationalism' of 
'blood and belonging' (Ignatieff 1994). These foreign-policy discourses were the background to how people from the Yugoslav region fleeing across, settling within, transiting over or temporarily crossing Western societies' borders were categorised - with implications for their legal and social status, the conditions on which they might belong or not belong within 'host nations', and, if one accepts that racialised ideologies still structure contemporary Western migration policies (Fekete 2009), the systems of racialisation they might encounter.

The EU 'temporary protection' system developed once 500,000 Bosnian refugees fled into the EU in 1992-3, codified into a 2001 directive (Sardelić 2017), represented an evolution of the organised asylum schemes that had covered east-central European 'Displaced Persons' after the Second World War (many unable or unwilling to return to homes now under state socialist control), refugees from the 1956 Hungarian Revolution and 1970s Vietnamese refugees. Western European governments had been making asylum increasingly restrictive since the 1980s, reducing state support for refugees and under-review 'asylum-seekers' to dissuade economic migrants from seeking settlement that way (Koser and Black 1999). These tightening asylum policies firmly distinguished 'refugees', to whom states owed protection under international law, and 'economic migrants', with no inherent right to settlement and (in most western European migration policy since the 1980s recessions) liable to be turned back; yet in many conflicts 'refugees' and 'economic' migrants were as hard to disentangle as 'post-socialism' and 'post-conflictness' in Bosnia.

While the 1945-56 refugees 'were mainly of European origin, and their cultural assimilation was perceived as relatively straightforward' (or even welcome bulwarks against Communism), the 1980s 'spontaneous' arrivals were 'generally ... from outside Europe' - that is, from the Global South - and appeared to be 'harbingers of mass South-North migration in the face of uneven economic development' (Koser and Black 1999: 524-5) - or, less obliquely, of ever-greater numbers of racialised migrants seeking to settle in western Europe. Indeed, Lucy Mayblin (2017) links 1980s asylum policy changes even more emphatically to most asylum-seekers from then on coming from former colonies 
and being racialised as non-white. This evolving history of migration and border control was the background for late-twentieth-century cultural racisms arguing that more mass migration would undermine autochthonous culture (sometimes including the liberal democratic tendencies ascribed to a certain national mentality), threaten public safety and health, and import migrants' own ethnic and religious antagonisms (Solomos 2003; Lentin 2004; Fekete 2009).

Post-Yugoslav refugees experienced EU 'protection' differently in different member states, or even German Länder. Most EU members gave many Bosnian refugees more permanent statuses over time, Sweden routed them into its asylum system immediately, and Germany stood out both in requiring Bosnians to return after Dayton and in devolving repatriation to individual federal units (Koser and Black 1999: 528-9). By the Kosovo War, meanwhile, western European political and media discourses had invented the category of 'bogus asylum-seeker' as a suspicious, racially different figure. Both eastern European Roma and migrants/refugees from Kosovo (some of whom were Roma) were inscribed into this category on entering or attempting to enter the EU. ${ }^{13}$ In Britain, the construction in some towns of a colloquial 'Kosovar' category, informed by antiziganist stereotypes, for both groups prefigured the more widespread racialisation of east European migrants after 2004, when Britain did not impose transitional freedom-of-movement controls on the east European 'accession eight' states. ${ }^{14}$ East Europeans were caught between the 'institutional racism' of migration policy favouring EU citizens over Global South citizens as labour migrants, and tabloids still directing late-1990s racialised tropes of flooding, criminality and antiziganism against them (Fox, Moroşanu and Szilassy 2012: 680). ${ }^{15}$

Associations between the Yugoslav region and disorder would also draw together migration and security in the case of sex work. The Yugoslav region was both an origin-point and (with so many foreign troops and officials present) a destination for sex-work migration, some facilitated by security contractors, IPTF officers and peacekeepers (Haynes 2008: 1794-8). Spatialised hierarchies of modernity (eastern Europe less modern, eastern Europeans lacking agency) have informed prevailing 
representations of sex-workers, and women subjected to the coercive labour of 'trafficking', since the 1990s (Andrijasevic 2007; Mai 2013; Suchland 2015). The stereotype of the east European 'prostitute' who might either migrate from the Yugoslav region or to it, 'white' by appearance yet on the margins of whiteness in global capital (Agathangelou 2004b), is one configuration of east European women's 'flexible "racing", racialising them as white when they are being desired and 'something more ethnic' when they are being exploited or having their agency cast into doubt in others' eyes depending on their position in the global political economy (Cerwonka 2008: 823). With anti-trafficking campaigns already targeting this node in the 'migration-security nexus' in the late 1990s, the convergence of migration policy and understandings of security had already begun before $9 / 11$, when the meanings of Islam in the Yugoslav region would intersect with transnational racialised Islamophobia.

\section{Racialised Islamophobia and the Yugoslav region before and after $9 / 11$}

The expansion of the 'migration-security nexus' through governments and international institutions, after 9/11, made 'Muslims' and people ascribed a Muslim appearance the primary targets of surveillance and suspicion to a degree that seemed to place Muslims beyond the boundary of Western political communities, treating them as racialised Others (Razack 2008). Post-9/11 Islamophobia compounded late-twentiethcentury Western cultural racisms that already stigmatised Islam as incompatible with liberal democracy, along lines inflected by specific national histories and experiences but with common assumptions that Islam was incompatible with a secular Europe or West. These myths themselves stemmed from the sixteenth- to eighteenth-century symbolic geographies that had defined first Christendom and then 'Europe' against the Ottoman Empire - the context for hierarchical Europe/Balkan oppositions in identity discourses inside and outside the Yugoslav region. 
Local identity discourses in the region, as elsewhere, actively translated post-9/11 securitised and racialised Islamophobia by adapting it to existing narratives about national history and enemies, while emphasising transnational Europeanness, Westernness and whiteness in those national narratives. More than half the Croatian journalists interviewed in 2006 by two Slovenian media scholars about how they had reported Croat war crimes against Bosniaks replied through discourses of the 'We had to fight against Islamic terrorism' type, with one commenting, 'I think that Croatia had to fight against Islamic terrorists like America or the West ... it is well-known that most of the Bosniaks are Islamic fundamentalists' (Erjavec and Volčič 2007: 14). Another recontextualised Croatian war aims in Bosnia as a campaign to prevent al-Qaida, specifically its then deputy leader Ayman al-Zawahiri, from establishing Bosnian cells to plot 'the plans for attacking the Western countries' (Erjavec and Volčič 2007: 15). A third respondent compared the Croat offensive with another conflict that the more powerful party had also framed as one where a democracy was defending its citizens against Islamic terrorism (Israeli operations against Hezbollah in Lebanon), and a fourth even combined ethnicised Islamophobia with neoliberal capitalism in arguing Croats had had to 'defend our property and market' against Bosniaks who had been appropriating Croat property and resisting supposedly necessary neoliberal reforms (Erjavec and Volčič 2007: 15, 17).

While the HVO was fighting the Army of the Republic of BosniaHerzegovina (ARBiH) in 1993-4, wartime Croatian media constructing stereotypes of that enemy had often called them 'mujahidin'. This both exaggerated the ARBiH's number of Muslim foreign fighters and capitalised on the SDA's growing religious nationalism to contend that Sarajevo ruling over Bosnian Croats would be an existential threat to their Catholic identity. The theme of anti-terrorism had, indeed, already characterised Croatian police responses to SDS militias placing roadblocks and taking over 'Serb-majority' municipalities in August 1990-May 1991. The Croatian government characterised these militias both as terrorists and illegitimate 'hajduks' (bandits) whom it was legitimate to suppress: indeed, Croatia's first paramilitary police unit, nucleus 
(alongside the volunteer National Guard) of the future Croatian Army, was the Anti-Terrorist Unit Lučko (a police headquarters outside Zagreb). Yet this was domestic, not global, terrorism: al-Qaida, al-Zawahiri and the notion of Islamists using Bosnia like Pakistan/Afghanistan to plan attacks on the West were not reference points in wartime Croatian media, nor did widespread wartime verbal and visual identifications between Croatian and US military strength identify Croatia with an active US/Western military struggle against terrorism. The journalists' post-9/11 narratives, conversely, immediately combined these. Existing xenophobias likewise became openly securitised Islamophobia in Slovenia after 9/11 in struggles over the building of a Ljubljana mosque (Vidmar Horvat 2010: 763).

Bosnian Muslims, meanwhile, performed different identity work after 9/11 by articulating Bosnian Islamic heritage as a model for a moderate, pluralist 'European Islam' comfortable with a multicultural, multifaith society. This argued that the history of Muslim-Christian coexistence in south-east Europe during and after Ottoman rule showed potential to prove Islam was not alien to European heritage (as long as the Balkans were integrally recognised as part of 'Europe'). Yet these discourses themselves arguably required a spatialising distinction between tolerant, pluralist Bosnian Islam, tempered by Europeanness, and a Middle Eastern Islam seen as fundamentalist and doctrinaire (Bougarel 2007). These arguments in turn reflected the politics and political economy of religion in postsocialist/post-conflict Bosnia, where Saudi and Emirati religious foundations were funding opulent new mosques while propagating Wahhabism - and threatening to pull Bosnia into the racialised zone of Islamist terrorism in twenty-first-century geographies of security.

\section{'Foreign fighters', jihadism and the war in Bosnia}

International Islamic voluntarism, hardly noticed by mainstream 1990s Western media when thousands of foreign Muslim men travelled to aid Bosniak refugees or fight alongside the ARBiH, appeared far more 
significant two decades later in Europe's contemporary history of migration, security and race. At least 300, potentially 3,000, foreign fighters volunteered as 'mujahidin' in 1992-5 to defend Bosnian Muslims and answer Islamist calls for militarised jihad. The Sarajevo government formed a 'Mujahids' Detachment' of ARBiH in August 1993 (Li 2016: 384-5), and at war's end, though Dayton required all foreign volunteers to leave, offered Bosnian citizenship to foreign fighters who had married Bosnian women or (like Libyans and Algerians) claimed they had no safe country to return to (Mustapha 2013: 746). Around this formalised, militarised production of transnational Islamist identity were much more diverse fundraising and consciousness-raising networks among Western Muslims.

Western Muslims organised aid convoys to Bosnia in similar grassroots humanitarian initiatives to those led by trades unions and left-wing movements, Christian churches, and the hundreds of private individuals who described themselves as moved by media images from Croatia and Bosnia to take action to stop the suffering. ${ }^{16}$ They also campaigned at home, like the British Pakistani women's group Al Masoom (active in Manchester 1990-6), who adopted 'Women in Black'-style silent protest (an anti-militarist feminist tactic from Israel/Palestine taken up in countries including Serbia) to campaign against human-rights abuses in Bosnia and Kashmir, employing an egalitarian understanding of their faith that made 'Islam the rallying cry for women's rights' (Werbner 2000: 320). Al-Qaida, however, had interests in deliberately blurring the lines between humanitarianism and paramilitary fundraising or even participation, and made Bosnia a node for recruiting young European Muslim men as militants (Kohlmann 2004) - indeed, some argue Bosnia 'played the central role' in catalysing British jihadism (Birt and Hamid 2014: 171).

Racialised suspicion by the British state blurred these lines further. Before as well as after 9/11, UK authorities often suspected mosque trustees of financing terrorism if they had supported humanitarian missions to Bosnia or other sites of Muslim suffering like Chechnya or Palestine (Fekete 2004: 9). Moazzam Begg (2007: 59-60), a British 
Pakistani arrested as an enemy combatant in Pakistan in 2002 and detained at Bagram and Guantánamo for three years, wrote in his autobiography that US and UK interrogators had frequently questioned him about visits to Bosnia: motivated by atrocity scenes in an amateur documentary on Massacres in Bosnia and Croatia and by hearing a Bosnian Muslim refugee in Birmingham narrate her rape by Serb soldiers, Begg first joined a foreign-fighter unit in Bosnia, then volunteered in Chechnya. 'Bosnia, in fact, became a site of memory and symbol of identity for some twenty-first-century Muslims facing racialised Islamophobia in the West.

Narratives of the Bosnian conflict as a genocidal attack against Muslims, part of a myth that addressed Muslims across borders and continents as part of a transnational, under-siege ummah (Roy 2004), are in retrospect as important an impact of the Yugoslav wars as the discourses of 'ethnic hatreds' or liberal internationalism that divided 1990s politicians, yet are marginal in the wars' transnational history as written to date (Li 2016: 381). Young Muslims in Europe and settlercolonial countries accessed them through Islamic bookshops, travelling preachers, student Islamic societies and mosques, where some Islamist organisers (including Abu Hamza, extradited to the USA in 2012, who preached from Finsbury Park Mosque in 1997-2003) spoke from personal experience as volunteers in Bosnia (Thomas 2014). Atrocity images from Bosnia circulated on underground videotapes around the incipient ummah just like equivalents in ethnonational diasporas, while resentment at Western failure to prevent genocide against Muslims not only helped to fuel the emergence of a separate Muslim political identity in Britain (distinct from 1970s-80s Black-Asian solidarity) but also 'led some British-born Muslims to reinvent the concept of the Ummah as global victims' (Modood 2006: 42) - meaning that, as Croat, Serb, Bosniak and Albanian ethnonationalists inside and outside the region pursued a politics of victimhood, similar dynamics and the same technologies were helping a globalised jihadi identity emerge.

Both technologically and thematically - in for instance the glorification of volunteers' militarised masculinities - this transnational ${ }_{\text {catherine Baker }-9781526126610}$ 
construction of community strikingly resembled how the region's ethnonational diasporas formed networks for aiding refugees and equipping (para-)military formations in the homeland (see Hockenos 2003). Sometimes, as when a Bosnian-born preacher in Vienna recruited Austro-Bosniaks such as Sabina Selimović and Samra Kesinović for Islamic State in Iraq and Syria (ISIS), ethno-diaspora and ummah even overlapped (Franz 2015: 10). ${ }^{17}$ Compared with ethnonationalisms with decades of associational culture behind them, the collective identity of late-twentieth/early-twenty-first-century transnational jihadism was more incipient as a political identification yet similarly dependent on victimhood narratives as explanatory myths. Addressing its audience through a shared religious identity as Muslim, cutting across boundaries of ethnicity and race, jihadism played off Muslims' lived experiences of Islamophobia at intersections of race, class and religion with a script that placed the marginalisation of young Muslims attracted to jihadism in a continuum with imperialist oppression of Muslims in Palestine and with the genocide of Muslims in Bosnia. The racialisation of Western Islamophobia, profiling all people of Arab or South Asian appearance as Muslims and potential terrorists whatever their religious heritage or practice, pervaded state surveillance and citizenship regimes after 9/11 (Razack 2008) and played into the jihadist narrative of global Muslim victimhood.

The formation of ISIS in 2014 transformed this historical narrative, previously propagated to support a transnational Islamist identity by al-Qaida as the basis for a transnational Islamist identity, into what was intended to become the foundational myth of an actual state. The techniques of building this state, on territories in Iraq and Syria taken over by militants during the Syrian civil war, were recognisable from wars and revolutions in the Yugoslav region and elsewhere - both the establishment of state structures, bureaucracy and taxation as quickly as a Communist Party in a twentieth-century civil war, and the concurrent campaigns to eliminate religious, ethnic and sexual minorities and minority/multi-ethnic cultural heritage (in this case, particularly preIslamic archaeological sites in Syria). While Bosnia like Palestine and Chechnya was part of jihadist collective memory, the implications of 
the deepening Middle East conflict for identification with/against Islam were social facts for Muslims in the Yugoslav region and (filtered through even more layers of national identification) diasporas. As hundreds of South Slav and Albanian foreign fighters travelled to Iraq/Syria, and Bosnian and Kosovar security services tried to prevent them, ${ }^{18}$ public debates in Bosnia-Herzegovina and Kosovo about Saudi-funded mosques or religious young women choosing to wear veils (when state socialism had unveiled women) incorporated positions towards transnational Islam into local social identities (Mesarić 2013). Yet this was only the latest example of a fusion between transnational, racialised migrationsecurity practices and post-Yugoslav collective identities that already underpinned European integration processes themselves.

\section{The Yugoslav region inside and outside 'Fortress Europe'}

Ever since the term 'Fortress Europe' emerged in the 1980s, the notion of European cooperation in securing EU borders and agreeing more restrictive immigration policies towards citizens of the Global South has been criticised as structurally racist - by giving Europeans, most of whom are white, privileged mobility over non-Europeans, most of whom are not (Balibar 2004), and reducing its racialised deportees and detainees to a state of 'bare life' outside the socio-political community (Walters 2002: 269; Vaughan-Williams 2015). The European border project has changed since the late Cold War, with material and virtual fortification of EU external borders accompanying the Schengen Area's relaxation of most internal border controls (projected in 1985 and included in the 1997 Treaty of Amsterdam). Perceived needs to keep out undocumented 'economic' migrants from eastern Europe and the Global South had already interconnected migration and security before 9/11 (Huysmans 2000; Faist 2006). After 9/11, however, the EU migration-security nexus accelerated into defending Europe from terrorism and unregulated immigration at once. 
Publicly and politically, this shift was framed as necessary, first because of 9/11, then the Afghanistan/Iraq wars, then the armed conflicts and political repression following the 2011 Arab Revolutions. These developments and the concurrent contingencies of EU enlargement altered the Yugoslav region's geopolitical position(s) relative to EU border security - from wholly on the outside at the millennium, towards a situation where some of it is standing on the margins of the inside and responsible for guarding against incursions from outside, while the rest of it is on the outside and is still responsible for guarding against incursions from even further out. Rearticulating post-Yugoslav national identities in this framework, as already seen with the Slovenian frontier myth, adapted existing historical narratives to twenty-first-century European and Euro-Atlantic racialised discourses of security.

The EU border project had the twin securitised purposes of counterterrorism (excluding people who could not be verified as non-terrorists) and restricting undocumented 'economic' migration (a security threat because of the danger they supposedly posed to nations' social peace and cultural cohesion). Its key sites included external EU land and maritime borders as well as airports in EU-adjacent states (like BosniaHerzegovina and Serbia) from which undocumented migrants could easily cross EU borders overground. Incorporating this immediate outside' into EU border controls, which the EU required its candidates and wider-partnership members to join, simultaneously widened the fortification and surveillance zone beyond the actual EU border, displaced some border management costs on to non-member states, formed part of the EU 'conditionality' regime for candidates, gave states a standard to meet in return for visa liberalisation, and offered an instrument of tutelage for disciplining neighbouring states' security services into EU border control ideologies and practices, including their racialised frameworks of governance and profiling. The Yugoslav region, covering much of the 'Balkan route' along which undocumented migrants travelling overland via Greece entered the EU (the alternative to the maritime 'Mediterranean route' between North Africa and Italy/Spain), thus took up yet another of its liminal geopolitical positions. ${ }^{19}$ 
The Schengen immediate exterior made first Slovenia, then Croatia, and eventually every ex-Yugoslav state including Kosovo a last line of 'defence' against overland migrants travelling towards Germany, Austria and Italy. The EU's own expanding external border placed Slovenia's detention and reception centres in 2004, and Croatia's in 2013, directly into the European network of camps. ${ }^{20}$ Even states unlikely to accede soon still had to improve airport and land border security, plus other 'conditionality' requirements, to qualify for EU economic aid for the Western Balkans. ${ }^{21} \mathrm{EU}$ training of Croatian, Bosnian and Kosovar border police during the 2000s has been critically called both a contemporary 'semi-protectorate' and an 'off-shoring and outsourcing' of border governance paralleling UK suggestions (from 2003) that 'third countries' on major migration routes should host 'transit processing centres' for asylum-seekers and Italy's 'push-back' policy (from 2009) of returning migrants who arrived by sea to Libya (Bialasiewicz 2012). ${ }^{22}$

Even as they were incorporated into EU border management, most post-Yugoslav states until 2009-10 were subject to Schengen visa requirements themselves, which travellers found frustrating, expensive and humiliating. ${ }^{23}$ Visa 'liberalisation' was thus a key EU incentive not only for achieving 'pillar' border security objectives (preventing organised crime, corruption, terrorism and undocumented migration, and introduction of biometric passports) and obtaining co-operation with the EU's external border fortification, but also, in this region, for pursuing the EU's wider vision for political integration (Flessenkemper and Bütow 2011). EU defence and security policy called for political integration of the 'Western Balkans' to prevent future ethnopolitical conflicts and, thereby, future humanitarian and security crises for the EU. The EU held out visa liberalisation to encourage Serbia, in particular, to co-operate on sensitive transitional justice matters (particularly extraditing Karadžić and Ratko Mladić) as well as border security reform; Macedonian authorities, meanwhile, prevented hundreds of Roma leaving Macedonia for fear they would seek asylum in the EU and jeopardise visa-free travel arrangements (McGarry 2017: 223). While part of the region eventually came within the racialised logic of EU-Schengen border 
control, other parts were still subject to them and sought, at least at governmental level, to move inside. Post-Yugoslav states were not the only part of Europe (so was Ukraine) asked to secure the EU external border while its citizens remained excluded by it - leaving border guards structurally compartable to Indian sepoys or Maghrebi spahis under a postcolonial reading of EU-eastern European relations. The Yugoslav region nevertheless stood out, not only because the EU gave border/ visa conditionality wider political aims there but also for being on a global, not just regional, route into the EU and, most distinctively, for what its inhabitants perceived as the rupture in their mobilities over time, compared with the Yugoslav era when most Yugoslavs believed they had much more freedom of travel than citizens of the Soviet bloc.

Following the visa restrictions imposed during the Yugoslav wars when EU states profiled post-Yugoslav and Albanian travellers as potential asylum-seekers and overstayers - with racialised suspicion of 'bogus' asylum-seeker falling hardest on Roma (Guild (ed.) 2014 2014) - symbolic geographies of European mobility in the 2000s shrank further. Slovenia's EU accession in 2004 placed an EU external border across a Slovenia-Croatia boundary which until 1991 had required no passport to cross. This became even less permeable, except for some residents near the border with localised provisions, in December 2007 when Slovenia and other 2004 joiners (except Cyprus) joined Schengen. This inversion of the hierarchy of international mobility made postYugoslavs' sense of humiliation and marginalisation particularly raw. It would be harsh to dub every such reaction 'exceptionalism'; yet it was perfectly possible to agree both that EU border policy was necessary for securing Europe against migration and terrorism, and that 'we' should not be subject to it.

Participation in and simultaneous subjection to EU border control left the Yugoslav region in yet another ambiguous global structural position, especially after 9/11. Twenty-first-century post-Yugoslav meanings of 'Europe' fused contemporaneous continent-wide racialisations of 'European' belonging in migration/security discourse with longer-term national historical narratives, just as late state socialist/ 
postsocialist 'return to Europe' discourses had been historically infused. Bosnian Muslims could narrate their history as a contemporary and historical 'bridge' between Islam and Europe (Bougarel 2007). Equivalent Slovenian, Croatian and Serbian narratives of national identity and bordering gained credibility and moral authority from resonance with the 'antemurale'/'bulwark' myth of the nation guarding ChristendomEurope against Islam (Chapter 2), just as in central European societies like Hungary and Poland where identification with national antemurale myths was re-produced in 2015-16 in the Visegrád Group's joint opposition to EU-wide quotas for Syrian refugees. ${ }^{24}$

Both bulwark and bridge myths, like any historical trope, are continually reinterpreted, constructing national identities in a changing present (Žanić 2005). Slovenia’s incorporation into EU border regimes, with media coverage of Slovenian police in border exercise providing public performances of security, for instance reaffirmed the bulwark myth by dramatising its relevance to a very different present from sixteenthto-eighteenth-century Austro-Turkish warfare (Mihelj 2005). Croatia's myth shifted too: in the 1990s it related primarily to Serbs and (during the HVO-ARBiH conflict) Bosniaks, ascribing them an essential easternness and Balkanness (while ascribing the opposites, equally essentialistically, to Croatia) based on their supposedly inescapable Ottoman heritage (Razsa and Lindstrom 2004). The NDH, in 1941-5, had also used it as historical precedent for standing with Germany against 'barbarism, Byzantinism, Bolshevism, and Orthodoxy', yet accommodated Bosnian Muslims within the Croatian people (Kljaić 2015: 160). In post-9/11 Croatian foreign policy, the Islamic threat against which Croatia performatively stood by joining the War on Terror was global, not Balkan, and the coalition against it was Euro-Atlantic and liberal. So long-lived and flexible was the sixteenth- to eighteenth-century antemurale myth that later forms of identification with transnational whiteness were perhaps grafted on to that very root.

While alternative visions of Europeanness and bordering existed in cultural and intellectual production, post-Yugoslav leaders did not express them in the way that Tito had championed an alternative 
diplomatic position. Post-Yugoslav state-of-the-nation cinema, with plots that juxtaposed members of various marginalised social groups to symbolise different aspects of post-Yugoslav crisis and dislocation, not uncommonly contained undocumented migrant characters from the Global South, particularly Chinese - though most lacked agency and primarily seemed to be there so that their visible, racialised difference could represent encounters with new and stranger forms of Otherness and symbolise postsocialist alienation (Rucker-Chang 2013). ${ }^{25}$ The new Yugoslav left, organising across post-Yugoslav borders and positioning itself within wider European struggles, linked migrant solidarity with socio-economic justice, environmentalism, anti-nationalism, LGBT equality and alter-globalisation (Razsa 2015) but found little mainstream political representation that would challenge post-Yugoslav governments' and nations' identification with Euro-Atlantic institutions and security practices. This identification, moreover, would even extend into participation in coalition warfare in Iraq and Afghanistan: as the EU induced states to harden their bulwarks within Europe, co-operation with NATO simultaneously projected that bulwark beyond national borders and even the region itself, in a conflict that many critics have described as driven by racialised constructions of security and Islam.

\section{Post-Yugoslav armed forces in the War on Terror}

Post-Yugoslav governments explaining participation in the War on Terror as a national interest adopted the same narratives as Western leaders in arguing that pre-emptive intervention against terrorist organisations that threatened European and Western values abroad was necessary to prevent them launching further attacks against the West. This placed them firmly within what European security studies calls 'Euro-Atlantic' institutions, an idea emphasising that Western diplomatic strategy for politically integrating the Yugoslav region and thus preventing future ethnopolitical conflict relied on the successor states' integration into NATO as well as the EU (Ó Tuathail 2005: 52). All post-Yugoslav 
states except Serbia, the target of NATO air strikes in 1999, aspired to join NATO, with Croatia and Slovenia seeking candidacy as soon as they won international recognition.

The symbolic politics of NATO as well as EU membership, for Slovenia and Croatia, performed a distancing from state socialist, Yugoslav and 'eastern' conceptions of security that in defence and foreign policy as in other political and social domains characterised the construction of Slovenian and Croatian narratives of national spatial/cultural identity. Both countries' military visual cultures - anticipated in Croatia by volunteers who, before the Croatian Army was regularised in January 1992, equipped themselves through surplus stores including Zagreb's (still-trading) 'American Shop' - drew on impressions of the contemporaneous US military freshly reimagined, post-Vietnam, by late-ColdWar film-makers as well as the US military itself (Senjković 2002). By 1994, with the Clinton administration (relatively) more involved in Bosnia, Slovenia had joined NATO's 'Partnership for Peace' (NATO's programme for potential future candidates), and Croatia was receiving US military assistance through a private contractor, eventually a decisive advantage in Croatian offensives against the Republic of Serb Krajina in $1995 .^{26}$

NATO itself, its members and candidates, and states and politicians rejecting affiliation with it, all attached membership symbolically to broader questions of how national identity related to prevailing scripts of 'Europe' and the 'West' in Cold War and post-Cold-War Europe (Fierke and Wiener 1999). NATO's first eastward enlargement, to the Czech Republic, Hungary and Poland (invited in 1997, admitted in March 1999), simultaneously symbolised these states'/governments'/ nations' search for 'identification with, and recognition by, the West' (Schimmelfennig 1998: 199); NATO's belief that military co-operation would promote liberal values and thus stabilise peace in a region where, a decade earlier, it had still expected to fight the USSR in large-scale ground warfare; a guarantee these states would not fall into Russia's sphere of influence; and a hierarchical calculation that these states had internalised NATO values most quickly (Kuus 2007). This was the central 
Europe to which 1990s Slovenian and Croatian leaders aspired. With Milošević's rump Federal Republic of Yugoslavia targeted by NATO ultimatums in 1998 then air strikes in 1999 over Kosovo, and NATO-led military forces in both Bosnia-Herzegovina (having replaced UNPROFOR after Dayton) and Kosovo (after June 1999), the temporalities of which states were, might be, or might never be 'ready' for NATO drew yet another symbolic boundary through the Yugoslav region.

Slovenia's NATO accession alongside Bulgaria, Estonia, Latvia, Lithuania, Romania and Slovakia in March 2004 preceded, and almost mirrored, ${ }^{27}$ the EU enlargement into eastern Europe in May, hardening a symbolic Slovenian 'acceleration' out of the Yugoslav region and into central Europe that gratified Slovenes who believed they had always been more naturally liberal and democratic than their 'Balkan' Others (see Longinović 2011). Croatia, a Partnership for Peace member since 2000, joined NATO with Albania in 2009. Macedonia, meanwhile, had been in Partnership for Peace since 1995 and a NATO candidate since 1999, but the Greece-Macedonia name dispute plus NATO evaluation of defence reforms held it back from accession. Bosnia-Herzegovina and Serbia both joined Partnership for Peace in 2006. The most decisive phase of NATO enlargement into the region therefore coincided with NATO's post-2001 transformation, following 9/11 and US air strikes against Taliban positions in Afghanistan, from a collective security organisation focused on defence of territory in Europe to a military coalition with combat as well as stabilisation missions overseas.

Many critics of the War on Terror, and its global structures of surveillance, intelligence, detention and interrogation in symbiosis with less covert 'kinetic' (ground combat, air strikes, anti-IED operations ${ }^{28}$ ) and 'non-kinetic' (military liaison, civil-military co-operation, training local security forces and state-building) operations in Iraq and Afghanistan, argue it employed and normalised a racialised narrative of Islamic menace to Western civilisation (Puar 2007; Razack 2008). This narrative essentialised Muslims and Islam into a global, civilisational threat, building on 1990s 'clash of civilisations' rhetoric (to which evidence from the Yugoslav wars had contributed) about religious and cultural 
difference as root causes of intercommunal conflict. Moreover, through US torture and interrogation methods in Iraq, Afghanistan, Guantánamo and CIA so-called 'black sites' globally, it aligned the coalition's most powerful member and thus its partners with a logic that has been argued to follow 'the racial-sexual grammar of chattel slavery' (Richter-Montpetit 2014: 58). Post-9/11 securitisation and racialisation of Islam (and of people with brown and Muslim bodies crossing borders) depended on pre-9/11 Western cultural racism. Even more deeply, the history of the Second World War's North Atlantic alliance that gave NATO its founding myth itself carries a vestigial whiteness if seen in continuity with the 'racialized peace' already forged, Srđan Vučetić (2011) argues, by Britain and the USA (later including France) at the fin-de-siècle.

Post-Yugoslav politicians and Atlanticist commentators primarily described their militaries' roles in Iraq and Afghanistan as contributing to state-building and democratisation. They might also suggest - as some post-Yugoslav troops deployed as peacekeepers in countries such as Liberia did - that their own countries' and militaries' recent experience of post-conflict reconstruction and defence/security reform gave them insights into the challenges of stabilisation after authoritarianism and war. ${ }^{29}$ Joining these coalitions helped post-Yugoslav militaries acclimatise to NATO standards as their accession pathways required, helped officers and diplomats to gain experience and status to progress to more powerful roles inside and outside NATO, and helped post-Yugoslav societies symbolically to perform an overcoming of and redemption from legacies of the 1990s wars. Critical race scholarship on the War on Terror would view this as simultaneously performing an attachment to whiteness.

Participation in NATO after 9/11 was a 'considerably changed strategic environment' (Šimunović 2015: 179) compared with post-Yugoslav governments' late-1990s expectations. The militarised identity narratives of 1990s Slovenian and Croatian nationalism were specifically about defending the ethnonation's homeland, simultaneously thereby - as a strong bulwark against Eastern threats - defending Europe, Westernness and Christianity. The War on Terror might therefore have also seemed like a considerably changed symbolic environment, with the nation's 
soldiers acting as junior but professional partners overseas to NATO allies rather than re-enacting the nexus between national heroism, strength and territory. Continuities between pre-9/11 post-Yugoslav militarised identity discourses and post-9/11 European/international security discourses nevertheless emerge through the notion of 'postnational' defence (Kronsell 2012). ${ }^{30}$

The idea of 'postnational' defence in twenty-first-century European security viewed national interests and defence as 'multinational', 'achieved in solidarity with others well beyond the borders' (Kronsell 2012: 3): for instance, co-operative pursuit of terrorists in Iraq/Afghanistan protected European cities by preventing terrorists from organising attacks there. Compared with NATO's late-1990s liberal interventionism, postnational defence related more specifically to the security of national territory and the nation's population, re-identifying them as part of the threatened Europe and West. By serving overseas, Croatian or another nation's soldiers were still, discursively speaking, defending the homeland. Especially for Slovenia and Croatia, such contributions could simultaneously represent a fulfilment of the promise of independence (when one pro-independence argument had been that Yugoslavia was preventing these republics from fulfilling aspirations for greater co-operation with Europe and the West); for Bosnia-Herzegovina and Macedonia as well as Croatia, meanwhile, coalition participation overseas cast the nation as providing, rather than receiving, stabilisation.

In ostensibly an utterly different context - European television - Serbia in the symbolic eastern-enlargement year 2004 had celebrated returning to the Eurovision Song Contest by performing a pastoral, gentle, distinctly national masculinity widely read as an alternative to the violently militarised masculinities of demagogues, war criminals and paramilitaries then associated with Serbia abroad (Mitrović 2010). Post-Yugoslav militaries' international public images - even Serbia's, which did not aspire to join NATO - underwent a similar transformation around ideas of gender, violence and peace. Their re-equipment for desert operations, anti-IED protection and compliance with NATO interoperability standards gave them new uniforms that differed from, yet in 
Slovenia/Croatia bore the same insignia as, those that denoted heroic defenders of the nation in the 1990s. ${ }^{31}$ The evolution of post-Yugoslav militaries' public image was symbolic as well as practical: by participating in NATO interventions overseas, whatever else those meant, postYugoslav militaries could access the same reframing of militaries and their masculinities as 'forces for good' (Duncanson 2013) that characterised NATO states' public narratives about militaries in general during the wars in Iraq and Afghanistan.

This reframing also reframed, at least in part, the gender of military participation, with counter-insurgency seeming to require new culturally aware and compassionate military masculinities and NATO adding gender analysts to missions (plus encouraging members to open more military posts to women) after adopting the Women, Peace and Security (WPS) agenda in 2007. Croatia’s Kolinda Grabar-Kitarović, assistant NATO secretary-general for public diplomacy in 2011-14, first embodied NATO's WPS commitment as its first female assistant secretary-general, then as Croatian president and commander-in-chief (2015-), and symbolised the evolution of Croatian military prowess since the beginning of the Homeland War (Croatia having now fulfilled Tuđman's goal of joining NATO). Yet WPS itself arguably reinforced 'racial-sexual boundaries' in international security (by perpetuating the frame of 'dangerous brown men' and failing to challenge peacekeeper sexual violence) even as it increased (white) women's equality (Pratt 2013: 772). In this postcolonial feminist perspective, even post-Yugoslav militaries' steps towards gender equality while involved with NATO were also, within deep structures of race, moves in a racialised war.

While post-Yugoslav states' contributions in Iraq/Afghanistan were subjects of public diplomacy, their involvement with the War on Terror within their borders was more covert. Though all post-Yugoslav national identity narratives interpreted the posited existential threat from Islamic terrorism through existing national myths about Islam and the (il)legitimacy of political violence, ${ }^{32}$ the covert War on Terror had strongest impact in Bosnia-Herzegovina and Kosovo, which had both the largest proportions of Muslim inhabitants and (through peacekeeping) 
the largest material US military presence. In Kosovo, the US's Camp Bondsteel, built as headquarters for NATO's multinational force in 1999, was long rumoured to be part of the CIA's global 'extraordinary rendition' network of secret interrogation sites, the covert infrastructure behind the spectacle of US detention at Guantánamo. The Council of Europe's human rights commissioner, Álvaro Gil Robles, alleged this after visiting Bondsteel in 2002, as did the Kosovo ombudsman, Marek Antoni Nowicki, to a European Parliament inquiry into secret US detention sites in 2007 (Carey 2013: 456). The International Committee of the Red Cross sought to hold the Polish, Lithuanian and Romanian states accountable after finding interrogators at several CIA sites in those countries had used torture (Carey 2013: 431). Kosovo's different configuration of sovereignty and accountability, with civil administration performed by the United Nations Interim Administration Mission in Kosovo in 1999-2007, created an 'accountability gap' (Visoka 2012: 190) in international governance and an even more ambiguous space into which detainees might disappear.

Other post-Yugoslav states were implicated in secret detention. The first European Court of Human Rights hearing on secret detention was the mistaken-identity case of Khalid El-Masri, a Lebanese-German man detained by Macedonian police who handed him to the CIA knowing he faced extraordinary rendition to Afghanistan (Carey 2013: 454-5). The Bosnian state's covert co-operation in the War on Terror became international public knowledge in 2004 during the so-called 'Algerian Six' habeas corpus case in the USA, involving six Algerian ex-mujahidin who had become Bosnian citizens and who were detained at Guantánamo in January 2002 after their extradition from Bosnia-Herzegovina.The men's location had been unknown for several weeks after their arrest by Bosnian federal police, though they had been transported to Guantánamo the next day (Maljević 2010: 266-7). Bosnia’s existing political problem about mujahidin given citizenship in 1995 gained extra parameters in the War on Terror's international context, anticipating how domestic polemics about Islamic militancy would combine with the wider European/international security context when ISIS escalated 
the jihadist campaign against European cities. Konstantin Kilibarda (2010: 44-5) reads post-Yugoslav co-operation with US interrogation and participation in 'imperialist' military intervention in conjunction with these states' adaptation to EU migration-security standards and their repatriarchalisation of social relations as expressions of the 'racialized subject positions' their collective national selves took up during accession to Euro-Atlantic institutions. These did not simply import the racialised logic of the War on Terror but, like any other transnational policy transfer (see Lendvai and Stubbs 2009), adapted international norms, discourses and practices to local conditions, exemplifying 'race in translation' (Stam and Shohat 2012) yet again.

Individuals from the Yugoslav region nevertheless took up more complexly racialised subject positions within the War on Terror, not just as troops in national militaries but also as civilian employees of the private military contractors supplying security personnel, drivers, firefighters, caterers, construction workers, logistics/IT specialists and other staff to coalition bases across Iraq, Afghanistan and rearguard locations. Such 'Third Country Nationals' (TCNs) are, even in the emerging literature on how gender and race intersect in the everyday security practices of private military security companies that recruit many Western military veterans and Gurkhas (see Chisholm 2015), often invisible, in roles further removed from person-to-person violence that still, in most twentieth-century warfare, would have been performed by state militaries (Li 2015a: 129).

Bosnia-Herzegovina is among ten countries named by Darryl Li (2015a: 129), alongside 'dozens' more all from the Global South, to have furnished significant numbers of TCNs to Iraq/Afghanistan. Its own recent history of military intervention with English as a lingua franca, plus the postsocialist, post-conflict economy's ongoing stagnation, created a stratum of Bosnians with experience of working in militarised, English-speaking settings, and few job prospects at home, who readily found TCN work (Baker 2012: 867). US forces relied on TCNs because their labour was cheaper than US citizens'; because, unlike locally recruited workers, they were not inherently suspected of belonging to local militant groups that were attempting to infiltrate coalition bases 
(though they could not obtain US citizens' clearance or trust levels either); and because their deaths would go unnoticed in the US, though they often became scandals in their home countries (Moore 2017). ${ }^{33}$

Workers from the Yugoslav region, as so often, occupied an ambiguous place in private contractors' racialised hierarchy. Keith Brown's study of Macedonian labour migration and empire suggests Macedonian and other post-Yugoslav TCNs ranked 'alongside Nepalis, Filipinos, and others whose labor, and lives, carry lower costs than those of "Westerners"' within coalition bases' ethnically and racially stratified configuration of labour and space (Brown 2010: 833). Nationality further inflected workers' exploitation: south and south-east Asian TCNs, for instance, experienced the overcrowding and wage theft to which subcontractors already exposed their co-nationals in other sectors in the Middle East, like construction in Dubai and Qatar (Moore 2017). As in so many past labour migrations from the Yugoslav region, the workers' access to whiteness was contingent and conditional, yet more available than for workers unambiguously racialised as non-white. Brown, inspired by Ann Laura Stoler's tracing of 'imperial ligaments' (Stoler 2006: xii) between Ohio tyre factories and Sumatran rubber plantations, argues through the early-twenty-first-century history of Macedonian TCNs in Iraq and early-twentieth-century labour migration to the USA from today's Republic of Macedonia that Macedonia's history, anthropology and sociology - by implication the whole Yugoslav region's - should contend with (global) empire as much as the more popular and familiar question of nation. This both facilitates and - a step beyond Brown requires scholars of postsocialism explicitly considering the region's position(s) in global formations of race. In 2015-16, another 'refugee crisis' in Europe brought this home.

\section{Race and the Yugoslav region during the refugee crisis}

The spectacles of militarised border security, and of grassroots migrant solidarity, produced from the Yugoslav region as Europe's 'refugee crisis' began manifesting in 2015 were not, however newsworthy, as striking 
a departure in post-Yugoslav relationships with European politics of belonging as they seemed; instead, they intensified and followed the practices and discourses that had already incorporated the region into the EU's (racialised) migration-security nexus after the break-up of Yugoslavia. Across the continent, dominant early-twenty-first-century narratives of 'Europeanness' implicitly and explicitly involved a hierarchical opposition of 'European'/'democratic'/'liberal' values against 'Islam' which was both spatialised (projecting 'European' and 'Muslim' values to different zones of the world or different areas of cities) and racialised (projecting suspicion of Islam on to any brown-skinned body and anyone whose dress and behaviour suggested they practised Islam). These forms of everyday anti-Muslim racism combined the xenophobic opposition to extra-European migration of late-twentieth/early-twenty-first-century European cultural racism with the War on Terror's racialised Islamophobia. Even before hundreds of thousands of refugees fleeing acute and structural violence in Syria, Iraq, Afghanistan, Libya and elsewhere became the centre of a policing and humanitarian spectacle after travelling through south-east Europe in large numbers in 2015, European institutions' geopolitics of migration and security had already drawn in and cut across the Yugoslav region.

The so-called 'refugee crisis' of 2015-16 was also an intensification of existing patterns and policies, not the unexpected equivalent of a natural disaster to which many Europeans likened it. It manifested when an increasing number of refugees arriving in Europe from Syria in particular - 487,000 in January-September 2015, double the whole 2014 figure (Holmes and Castañeda 2016: 12) - combined with maritime migration routes from North Africa that increasingly landed migrants in Greece not Italy, to join others from the Middle East and Afghanistan who came to Greece overland via Turkey. Although the EU's Dublin Convention obliged refugees' first member state of entry to process their asylum claims, Greece (impoverished by the conditions of its EU debt bailout) struggled to provide for them, while many refugees preferred moving onwards towards greater economic prospects and existing diaspora communities in Germany, Austria and Sweden. The EU 
Temporary Protection Directive of 2001 - passed after the Yugoslav wars to regularise the relocation of refugees from a catastrophic crisis around EU member states until they could safely return - remained unactivated. News media and 'migration cinema' had already made the overland 'Balkan route' through Macedonia and Serbia towards the EU (its external border now Croatia-Serbia) and Schengen (with key nodes at the Croatian-Slovenian, Croatian-Hungarian and Hungarian-Serbian borders) familiar to post-Yugoslav publics as a route along which smugglers would lead small groups of clandestine migrants into the EU. In summer 2015 the Balkan route's image became publicly visible, internationally mediated and daylit, as columns of refugees walking through post-Yugoslav rural landscapes recalled the 1990s displacements but contained differently racialised bodies.

Post-Yugoslav authorities' responses activated militarised narratives of policing, migration and security already established through participation in EU border fortification. All insisted they should be transit not host countries, indeed created 'hyper-temporary' legal statuses to facilitate refugees' movement north even before Angela Merkel overrode Dublin by appearing to invite refugees directly to Germany (Sardelić 2017: 3). In June 2015, Macedonia introduced a new temporary asylum status giving refugees seventy-two hours to transit the country (from Greece to Serbia) rather than having to make clandestine entry and exit. Those travelling by rail, on railways depleted by state cutbacks during the European financial crisis, gathered at Gevgelija near the MacedonianGreek border, with by late August up to 1,000 people arriving daily, anxious to get ahead of Hungary's planned new border fence. Images of Macedonian police in camouflage uniforms firing stun-grenades and tear-gas at refugees who had taken direct action to board trains before Hungary closed its border briefly made Gevgelija a site of spectacularised crisis alongside Lampedusa, Kos and Calais. Belgrade, like Budapest's Keleti Station, soon became a major waypoint on the 'Balkan route, where refugees waiting to travel to Budapest first camped in a park by the main bus and railway station, then also at Miksalište, an alternative cultural centre in the Savamala district earmarked by city authorities 
for gentrification. Volunteers at both sites, near Croatian and Macedonian border-crossings, and in smaller towns through which refugees passed, mobilised to offer refugees food, clothing and information, well beyond what post-Yugoslav states with their few asylum centres had been equipped to provide.

The discourses with which politicians across eastern Europe rejected large numbers of Muslim refugees settling in their countries - even under EU-wide quotas finally agreed in May 2016 - made it indisputable that race and whiteness, not just ethnicity, were integral to national identity construction in early-twenty-first-century postsocialist Europe. Leaders of the Visegrád states, rejecting German proposals for EU-wide refugee relocation, openly argued (citing the Paris, Brussels and Nice shootings and the Cologne sex attack) that Muslim refugees were unacceptable national security risks who could not be integrated into national life. Post-Yugoslav leaders also constructed the scale of migration as a threat to national and European security, but with the important difference that their region was already receiving many refugees: their priority was to establish their countries as transit states not long-term resettlement/relocation destinations. Kolinda Grabar-Kitarović, speaking in September 2015 as Hungary was fencing off its border, drew on transnational discourses about terrorist infiltration in distinguishing 'real refugees' from 'people with forged Syrian passports, who ... have other aims in entering the EU' and 'present[ed] a potential security threat'. Even for 'real' refugees, however, Croatia could 'only be part of the transit route' because, amid high rates of unemployment and economic emigration, 'Croatia must take account of its own people and its developmental conditions ... We can show a human face, but we must, above all, take care of our own citizens' (Benčić 2015a).

The region's grassroots relief and solidarity movements, meanwhile, recreated alternative geopolitics that both evoked everyday public memories of being refugees and hosts during the Yugoslav wars and had at least potential to revive memories of everyday connections with the Middle East and North Africa that in socialist Yugoslavia had been part of many people's lifeworlds. The largest initiatives, in Belgrade, 
saw volunteers organise semi-permanent refugee relief centres at 'Info Park', near the stations, and 'Mikser House', in Savamala (Stojić Mitrović 2016). Groups such as Help the Refugees in Macedonia, founded in April 2015 after fourteen Somalis and Afghans were killed while walking on the railway near Veles, and Are You Syrious?, founded in Zagreb that August before expanding into 'an international citizens' initiative ... from Serbia to Slovenia, used Facebook and collaborative apps to co-ordinate volunteers and donations, fundraise internationally and inform followers about conditions on the Balkan route - an important service for refugees themselves given states' frequent policy changes. Their voluntarism resembled public responses to the severe 2014 floods in the region, when grassroots solidarities across post-Yugoslav borders had likewise compensated for post-Yugoslav governments' incapacity.

The presence of so many people from Africa and the Middle East in post-Yugoslav cities, especially Belgrade, meanwhile began to evoke memories of everyday Non-Aligned connectivities, which, combined with widespread public memory of 1990s displacement, might have accounted for relatively more welcoming social attitudes towards refugees compared with the Visegrád states. Fluent speakers of post-Yugoslav languages with heritage knowledge of Arabic, their family histories often a product of Non-Aligned mobilities, were in particular demand as volunteer interpreters and activist-translators. Some were themselves former refugees, such as Saf Alobaidi, a Syrian horticulturist and civil engineer who fled to Serbia in 2007, interpreting in 2015 for the United Nations High Commission for Refugees at the Banja Koviljača refugee centre where he had originally been sent - a centre opened in 1965 for 'exiles from South America and Eastern Europe' seeking asylum in socialist Yugoslavia (Kremer 2015). Others were former Non-Aligned students or their children, such as Tomas Valter, an Assyrian Christian from Basra who came to Yugoslavia to study medicine in 1968, or Rima Aboughazale, whose Lebanese father had moved her family from Belgrade to Beirut before Lebanon's civil war forced them to return. Here, as so often, language contacts (so often overlooked) revealed everyday yet neglected connections between regions that scholarship often keeps 
separate: the histories behind which languages people communicate in, who performs written/spoken mediation between languages, or how anyone involved came to know the languages they use are windows into the micropolitics of humanitarianism, migration and war (Footitt and Kelly (eds) 2012).

Official reactions to migrant solidarity movements in 2016, however, showed a politics of demobilisation as well as mobilisation around the refugee crisis. Savamala's contentious redevelopment into the 'Belgrade Waterfront', with Emirati finance and the Serbian prime minister Aleksandar Vučić's support, saw masked men clear an area including Miksalište in April 2016. Miksalište, which had helped up to 600 refugees daily, reopened elsewhere two months later but closed due to lack of capacity in July, with Info Park itself having to close in October and more than a thousand refugees camping in unheated buildings over winter (Bjelica and van Bijlert 2016). The very confluence of capital, dispossession, protest and racialised precarity surrounding Savamala was already in play before the refugee crisis: the resettlement of 178 Roma households to peripheries of Belgrade when city authorities cleared their camp under the Gazela bridge for development, and the civil society mobilisations in protest, exemplified the convergence of 'translocal discourses and institutional structures' (Kilibarda 2011: 593) later mediated through the refugee crisis. The lens of global raciality reveals that the Gazela bridge and Savamala were both part of the same 'racialized urban restructuring' (Kilibarda 2011: 593) in Belgrade.

Simultaneously, the region's border management projects and security discourses interacted with racisms elsewhere: the crisis's very course, with states opening or closing borders in response to refugees' changing routes and reported public attitudes to nations acquiring large Muslim communities, depended on complex interactions between many states' authorities, EU institutions and European legal instruments. During the June 2016 Brexit campaign, a controversial UK Independence Party poster, unveiled hours before a white man with neo-Nazi connections killed the Labour MP Jo Cox (a Remain supporter who had lobbied for the UK to accept more refugees), showed a column of mostly male, 
brown-skinned refugees, as if marching to Britain as invading terrorists, and read 'Breaking Point: the EU has failed us all; we must break free of the EU and take control of our borders'. Its nexus of sovereignty, securitised migration, Islamophobia, race, masculinism and take-backcontrol discourse epitomised the transnational populist right of 2016. The photograph came from a grassy road near the Slovenian-Croatian border, mobilising a nest of imaginaries of violence and crisis into a fantasy that Maja Lovrenović (2016) summarises as '[r]efugees from the "balkanized" Middle East marching through "the Balkans" to "balkanize" Europe'. In one sense it was entirely removed from the Balkans; in another, it showed the racisms of post-imperial Britain and the Yugoslav region were interdependent, not just parallel.

In 2015-16, the need to situate the Yugoslav region within the politics and mobilities of a refugee crisis at the convergence between the War on Terror's consequences, the suppression of the Arab Revolutions and the effects of colonial and neo-colonial structural violence on people, economies and environments in Africa made explicit what should have been apparent before: a lens limited to 'Europe' could not explain the region's history and the construction of collective identities related to (not 'contained within') it. If, as Peter Gatrell (2016: 2-3) writes, 'future historians [who] write about forced migration in and around the Mediterranean during 2015-16' will need modes of 'thinking through oceans ... beyond the boundedness of the modern nation state', a longue-durée post-Ottoman history, linking the Yugoslav region and Syria-Iraq-Libya throughout the twentieth and twenty-first centuries not just up to the nineteenth, might never have been more timely but is largely still to be told. ${ }^{34}$ For the Yugoslav region, and other peripheralised areas where nations were not heavily involved in colonialism as political entities, centring such past and present connections does more than offer the area a global context: it also signals what routes show that race, distinct from yet related to ethnicity and religion, undeniably forms part of identity-making projects in the region.

This holds true both for the 1990s and after 9/11. Indeed, the 1990s convergence of postsocialist ethnonational homogenisation and 
identification with 'Europe' with transnational discourses of cultural racism in reaction against postcolonial demographic change gave race and whiteness valences that would feed directly into the convergences of the early twenty-first century, between the existing EU migration-security nexus, the War on Terror's further polarisation and securitisation of 'Europe' against 'Islam', and the campaigns of political violence in European cities that militants planned as a result. These were historically specific expressions of racialisation and whiteness, shaped in interaction with other contestations of belonging outside or projected on to the Yugoslav region. The presence of race within post-Yugoslav identitymaking, however, was not a novel product of postsocialism; as previous chapters have shown, it had existed as long as, and had deeply informed, notions of nationhood itself.

\section{Notes}

1 Even though Pieterse had previously studied Western representations of Africans (1992), he did not explore race in comparing Bosnia, Rwanda and Somalia (1997).

2 Karadžić, so-called 'architect of the Bosnian Genocide' (Donia 2015), was the wartime RS president; Plavšić was one of his vice-presidents. Another psychiatrist, Jovan Rašković, founded the Serb Democratic Party (SDS) in Croatia shortly before Karadžić founded one in Bosnia-Herzegovina (Bjelić 2013: 1).

3 The Sarajevo-born writer Igor Štiks expresses this in his 2006 novel Elijahova stolica (Elijah's Chair), when a Sarajevan actress tells a Viennese journalist during the siege: 'Today's Europe may, in fact, have its true representatives in Karadžić's army, not us. Karadžić's men are the heralds of the continent's future, of ethnicization, religious hatred, division, of racial purity and resistance to the demographic threats of the racial, national, and religious others. Champions of the new European xenophobia, they are the truly European players on the Balkan playing fields, not us' (Štiks and Elias-Bursać 2016).

4 Though more difficult than for the central European 'Visegrád Group' which many Slovenians considered natural comparators: Slovenia joined the EU with them (2004), but only signed its preliminary 'Europe Agreement' in 1996, whereas Czechoslovakia, Hungary and Poland signed theirs in December 1991 (with new Czech/Slovak agreements in December 1994).

5 Slovenia's 'Chinese migrant' films (see Rucker-Chang 2013) were therefore made against this background. The 2000 rise is particularly striking since 1999 included the Kosovo War. 
6 The original Croat Democratic Union (HDZ), founded by Franjo Tuđman (Croatian president 1990-9), held parliamentary power in Croatia throughout the 1990s.

7 Thomas Balmès's 1996 documentary Bosnia Hotel follows three Samburu men reflecting on their service as Kenyan peacekeepers in Bosnia-Herzegovina as an intercultural encounter (Ernst-Luseno 1998).

8 Their song 'Unproforci, pazite na ceste' ('UNPROFOR, caution on the roads') threatened UNPROFOR soldiers with anal rape, insulting Nambiar as 'a moustachioed faggot [brkati pederu]' who had 'let the Serbs shit on' him - implying his failure to defend Croatian sovereignty was also a failure of masculinity, possibly even projecting a 'repressed homoerotic fascination with the racial "Other"' (Longinović 2000: 638) on to the abuse.

9 Two Western European analysts called the post-Dayton order a 'European Raj' (Knaus and Martin 2003), causing some controversy in the Bosnia/peacebuilding literature.

10 Germany, India, Jordan and France all contributed 120-165 officers to that cohort, Pakistan 98 and Ghana 86; the USA contributed 228. The IPTF's 31 other contributing states in 1997 mostly sent 30-60 (UNMIBH 1998).

11 Or so it seems - however, late-1990s Tuzla also became the centre of Bosnian hip-hop, a connection deserving further research. The Tuzla-based rapper Edo Maajka's song 'Legenda o Elvisu' ('The Legend of Elvis', 2004) is about the child of a married Bosnian cleaner and an African-American soldier.

12 Kaplan's follow-up The Coming Anarchy reported on West Africa with even more essentialised assumptions about the causes of conflict there and even more alarm about their implications for the West (Kaplan 2000).

13 See McGarry (2017: 234) on the precarious status of Kosovar Roma once EU member states expected them to return to Kosovo.

14 In fact there were ten - but Cyprus and Malta both had the smallest populations and were former British colonies, thus were largely excluded from constructions of 'EU enlargement' as a social problem for Britain.

15 One UK study with white Hungarian/Romanian migrants in 2009-11 found they distanced themselves from xenophobia by emphasising their whiteness and Europeanness in interviews so much as to deny discrimination they were actually facing (Fox, Moroşanu and Szilassy 2015).

16 All grassroots foreign voluntarism during the Yugoslav wars is under-researched, but see Janković (2012).

17 Sixteen-year-old Kesinović and fifteen-year-old Selimović, whose refugee parents settled in Austria in 1992-5, travelled to Syria in 2014, becoming what Western media frequently called 'poster girls' for the ISIS propaganda strategy of promising very young Muslim women empowerment and fulfilment by separating from their families, settling in ISIS territory, marrying jihadis and raising children who would grow up in the Islamic State. Awaiting them instead was a system of sexualised coercion where they were reportedly forced into sex with arriving male jihadis - treatment to which VRS guards in eastern Bosnia had subjected captured Bosniak women in 1992-5 - while ISIS manipulated their images on social media to inspire other Muslim teenagers 
to follow them (Perešin and Cervone 2015: 502). Selimović was missing by the end of 2014, and Kesinović is thought to have been beaten to death in 2015 while escaping from a house in Raqqa.

18 Gornja Maoča near Brčko in north-west Bosnia, home to a Salafist community including former mujahidin, was already a reputed 'Wahhabi village' before it provocatively flew an ISIS flag in 2015.

19 While today's 'Balkan route' primarily connotes movement of people, in the 1990s it implied drugs.

20 Croatia’s first immigration detention facility opened at Ježevo in 1996. The 2000 asylum 'crisis' saw Slovenia open a new detention centre at Postojna.

21 This assistance scheme was first called PHARE (Poland and Hungary: Assistance for Restructuring their Economies) and covered eastern European states seeking EU accession, though not Serbia or Montenegro. A dedicated scheme for the Western Balkans - Community Assistance for Reconstruction, Development and Stabilisation - was founded in 2001 covering all Yugoslav successor states except Slovenia, plus Albania. This became the Instrument for Pre-Accession Assistance in 2007. The phrase 'the Western Balkans', as an EU euphemism for ex-Yugoslavia, extended to Albania, generally excluded Slovenia, related increasingly ambiguously to Croatia as Croatia's status changed, and diplomatically avoided evoking 'Yugoslavia' at all.

$22 \mathrm{EU}$ assistance was also linked to border security reforms in Libya, where 50 per cent of state border security and surveillance equipment purchases were EU-funded in 2009-11; authorities during the 2011 revolution used this against protestors and rebels in Libyan cities (Bialasiewicz 2012: 859).

23 Schengen permitted citizens (with biometric passports) of Macedonia, Montenegro and Serbia visa-free travel in December 2009, adding Bosnia-Herzegovina and Albania in December 2010.

24 On narratives of present/past Polish encounters with Islam, see Narkowicz and Pędziwiatr (2017). The Visegrád Group comprises the Czech Republic, Slovakia, Poland and Hungary.

25 Yugoslavs had of course encountered global racial Otherness in Non-Aligned students (though more were African than east Asian): here, too, the forgetting of Non-Alignment makes Yugoslav history less globally connected than it deserves.

26 Tuđman had signed the Washington Agreements in January 1994, ending the HVO-ARBiH conflict in Bosnia-Herzegovina with this incentive.

27 Romania and Bulgaria joined the EU in 2007.

28 Improvised Explosive Devices (IEDs) were heavily used in both Iraq and Afghanistan against coalition troops.

29 Much further in the background was the history of Yugoslav-Iraqi engineering/ construction co-operation under Tito and Saddam (see Kulić 2014).

30 YouTube users uploading montages of Croatian soldiers in Afghanistan alongside montages celebrating Croatian soldiers in the 1990s war also drew such a continuity.

31 Bosnian defence reform had created one integrated military from the three wartime formations; the Serbian military had changed its insignia in 2006 after the separation of Serbia and Montenegro. 
32 Some Croatian nationalists would both have denounced Islamic terrorism and celebrated Zvonko Bušić, the Croat émigré hijacker of a 1976 New York-Paris flight, as a patriot fighting for independence from Yugoslavia.

33 These included Iraqi militants' killing of two Macedonian contractors on video in October 2004 (Brown 2010: 816). Killers of a Croatian oil-worker in Egypt in 2015 released an image stating he had been killed 'for his country's participation in the war against the Islamic State' (Withnall 2015).

34 Thanks to Ljubica Spaskovska for prompting this observation. 